\title{
Transnational Labour Solidarity in (the) Crisis ${ }^{1}$
}

\author{
Andreas Bieler, University of Nottingham, Nottingham, United Kingdom
}

\begin{abstract}
The global financial crisis as part of globalisation has put labour movements under pressure around the world. This poses yet again the question of transnational solidarity. As a result of uneven and combined development, individual labour movements find themselves in rather different positions with contradictory interests. The purpose of this article is to assess conceptually possible labour strategies towards transnational solidarity against the background of the structuring conditions within the global economy.

The article is organised into two parts. First, the structuring conditions of capitalism will be charted including processes of uneven and combined development. This will provide the basis for the second step of conceptualising the potential agency of labour and its possibilities to establish relationships of transnational solidarity despite the unevenness of global development. In this discussion the definition of 'labour' itself will be problematized and concepts of 'labour aristocracy' and 'false consciousness' critically examined.
\end{abstract}

\section{KEYWORDS}

Class agency, class struggle, false consciousness, labour aristocracy, structuring conditions of global capitalism.

\section{Introduction}

The global financial crisis has put labour movements under pressure. While states had initially bailed out one financial institution after another, it is now workers who have to pay the bill. The example of the Greek people, being confronted with numerous austerity programmes in order to ensure further loans by the IMF and EU, is only one of the most dramatic cases. Austerity is pushed across countries and regions putting downward pressure on workers' conditions around the world. The purpose of this article is to assess conceptually labour's possibilities to establish transnational solidarity in resistance to exploitation.

When reflecting on the current structuring conditions of the global economy, it is essential to emphasise its capitalist nature. This article, thus, adopts a historical materialist approach, which argues that the way production, understood in a broad sense, is organised, influences all other aspects of life and social relationships. Many analyses within International Political Economy focus on globalisation, crises and inequality. The way this is done, however, is often ahistoric in that they take 
the separation of state and market, and of state and civil society uncritically as the starting-point of their investigation (e.g. Cerny, 2010; Held and McGrew, 2002; Waltz, 2000). They discuss in what way states, i.e. the political, are in a position to re-establish control at the national and/or international level over markets, i.e. the economic. They conceptualise the role of civil society and how it may be crucial in re-asserting control over the economy. Thereby, it is, however, overlooked that the fact that states and markets, civil society and the state, the economic and the political, do appear as separate is rather specific to capitalism (Burnham, 1995). In order to understand why they appear as separate, it is necessary to analyse the way capitalist social relations of production are organised around the private ownership of the means of production, i.e. capital, and wage labour, i.e. workers. As a result, the extraction of surplus labour is unlike in feudalism not directly politically enforced, because those, who do not own the means of production, are 'free' to sell their labour power (Holloway and Picciotto, 1977: 79; Wood, 1995: 29, 34). Nobody is forced to work for a particular employer. However, without owning one's own means of production, people are indirectly forced to look for paid employment. They are forced to sell their labour power in order to maintain their livelihoods. Unless this historical specificity of our current period is understood, any analysis of the global economic crisis and the possibility of transnational labour solidarity in resisting exploitation cannot be grasped. Hence the need for a historical materialist approach.

Within the mainstream literature, but also more open, critical readings, historical materialism is often rejected for its apparently inevitable economic determinism. Erik Olin Wright, for example, argues that 'the classical Marxist theory of alternatives to capitalism is deeply anchored in a deterministic theory of key properties of capitalism's trajectory' (Wright, 2006: 104). Such easy dismissals are often based on a rather superficial engagement with Marx and wider Marxist literature, overlooking the many non-determinist historical materialist approaches. And yet, even from within historical materialism, there is sometimes an uneasiness voiced about structural varieties of Marxism, which overlook the importance of (class) agency. In a survey of classical Marxist political economy, Harry Cleaver outlines how many of these authors including Bernstein, Kautsky, Lenin and Luxemburg separated the economic from the political. 'By reading Capital as political economy they limited themselves to a critique of capitalist anarchical instability or exploitative nature' (Cleaver, 2000: 34). Agency was overlooked.

In response to such an ahistoric, political economy Marxist approach, Cleaver suggests a political reading of Marx, which puts class agency at the heart of analysis. Rather than identifying laws related to the structure of the capitalist social relations of production, he emphasises that 'the "laws of motion" of capitalist society are the direct product of the class struggle and denote only what capital has had the strength to impose, given the rising power of the working class' (Cleaver, 2000: 88). Similarly, Alf Nilsen considers structures to be purely the result of class struggle. They 'are not static', Nilsen argues. 'Rather they are internally contradictory totalities that undergo constant processes of change as a result of contention between dominant and subaltern social groups over the structuration of needs and capacities' (Nilsen, 2009: 114). The main emphasis is on praxis, on class struggle, the outcome of which determines the structural, institutional setting.

By contrast, the investigation here is started through a focus on the social relations of production, which by default implies that structure matters. Of course, (class) agency remains crucial, but as the introduction to this special issue also insists, strategies cannot be analysed in isolation of structure. It is accepted that structures are always instantiated by human beings, but this may be the result of actions in the past, with structures opposing social class forces as objective 
constraints in the present. These structures do not determine agency in the present. They may prevent, constrain or enable agency and they may be changed by collective agency. Thus, within any particular structural setting, or particular set of structuring conditions, social class forces can choose from a limited variety of different strategies (Bieler and Morton, 2001: 16-29). Hence, the investigation in this article is organised in two steps. First, there will be an assessment of the structuring conditions of the global economy. Unless the ground for potential strategies is understood well, reflections on necessary agency of resistance are likely to result in wishful thinking, in suggestions for strategies, which bear no resemblance with the concrete reality of what is possible. As Robert Cox argues, it is the purpose of critical theory to challenge existing society but within the realm of the possible (Cox, 1981: 130). While an essential starting-point, however, simply outlining the structuring conditions is not sufficient when thinking about the potential for active resistance. Too often, analysis only concentrates on outlining existing power structures. Hence, the second part of this article looks at the agency of labour and here in particular the possibilities for transnational solidarity against exploitation.

\section{The Structuring Conditions of the Global Economy}

It is the particular set-up of the capitalist social relations of production around the private ownership of the means of production and wage labour, which implies two crucial structuring conditions. First, because labour and capital both reproduce themselves through the market, there is a constant emphasis on competitiveness and the related pressure for further technological innovation in a relentless struggle for ever higher profit levels. As Marx noted, 'under free competition, the immanent laws of capitalist production confront the individual capitalist as a coercive force external to him' (Marx, 1867/1990: 381). In order to remain competitive every capitalist is forced to innovate production in order to produce more goods at lower costs, generally through the introduction of new technology in the production process. 'If accumulation is not carried on, if the apparatus of production is not constantly modernized, then one's own enterprise is faced with the threat of being steamrolled by competitors who produce more cheaply or who manufacture better products' (Heinrich, 2012: 16). Nevertheless, the technological advantage gained is never permanent, because as soon as one capitalist has moved ahead, others are forced to catch up in order to remain competitive themselves. Once this step has occurred, there is then renewed pressure to move ahead technologically yet again, and so forth (Harvey, 2006: 120). In other words, this constant pressure towards technological innovation is a key structuring condition of the capitalist social relations of production. 'Competition subordinates every individual capitalist to the immanent laws of capitalist production, as external and coercive laws' (Marx, 1867/1990: 739).

Nevertheless, what is logical for the individual capitalist, is problematic for capital as a whole. When every capitalist attempts to produce more goods with fewer workers through the application of new technology, there will be fewer and fewer people, who can actually buy those goods. In other words, there are tensions between growth and technological progress, which are 'just too powerful to be contained within the confines of the circulation of capital' (Harvey, 1985: 132). Hence, there will be a crisis of overproduction and, as a result, a declining rate of profit. 'We see here', Harvey argues, 'the necessary contradiction that arises when each capitalist strives to reduce the share of variable capital in value added within the enterprise while speculating on selling his output to workers employed by other capitalists' (Harvey, 2006: 134). Expressed differently, there is a situation of a 
surplus of both capital and labour, which can no longer be brought together in a productive way within the capitalist social relations of production, a 'state of overaccumulation' (Harvey, 1985: 132). Thus, Marx identified the following economic cycle: 'feverish production, a consequent glut on the market, then a contraction of the market, which causes production to be crippled. The life of industry becomes a series of periods of moderate activity, prosperity, over-production, crisis and stagnation' (Marx, 1867/1990: 580). It is this crisis tendency of capitalism, which can be identified as the second structuring condition of capitalism. The current global financial crisis clearly demonstrates this dynamic. In order to overcome the crisis of overaccumulation in the early 1970s and the related decline in the rate of profit, a financial fix with a shift towards investing in financial markets to make profit took place (Harvey, 1985: 137-9). More and more new, innovative financial instruments were set up in order to develop new areas for the accumulation of surplus value. This also included the highly risky sub-prime mortgages. What was, however, logical for one financial company due to the initially high profit rates in the subprime mortgage market, turned out to be disastrous for the whole financial system. As soon as all financial institutions became involved in this risky area, the bubble burst revealing the fragile foundation of these financial instruments.

Rosa Luxemburg had already pointed to 'the inherent contradiction between the unlimited expansive capacity of the productive forces and the limited expansive capacity of social consumption under conditions of capitalist distribution' (Luxemburg, 1913/2003: 323). These crises, she argued, cannot be solved within capitalism itself. Instead, new markets have to be opened up elsewhere. 'The decisive fact is that the surplus value cannot be realised by sale either to workers or to capitalists, but only if it is sold to such social organisations or strata whose own mode of production is not capitalistic' (Luxemburg, 1913/2003: 332). Ray Kiely engages critically with Luxemburg's analysis of the outward dynamic of the capitalist mode of production. Historically, capitalist accumulation did not functionally depend on absorbing ever more non-capitalist space. Before World War I, for example, most capital was invested in, and trade took place between, industrialised countries (Kiely, 2010: 79-81). And yet, at the same time, it is a fact that capitalism did expand outwardly in encompassing the whole globe. Already in 1848 Marx and Engels wrote about how capital overcomes periodic crises 'on the one hand through the enforced destruction of a mass of productive forces; on the other through the capture of new markets and a more thoroughgoing exploitation of old ones' (Marx and Engels, 1848/1998: 18). The enforced destruction of productive forces and a more intensive exploitation of existing capitalist social relations of production links to Kiely's emphasis on developments internal to industrialised countries. The capture of new markets, however, refers to Luxemburg's focus on outward expansion. The notion of uneven and combined development becomes relevant especially in relation to geographical outward expansion of capitalist accumulation.

It was Leon Trotsky, who introduced the notion of uneven and combined development in his book Results and Prospects in 1906, when analysing the particular location of Russia within the world economy. While Russia was economically backward based on a large sector of inefficient agriculture indicating the unevenness of development in relation to advanced Western countries, a number of small pockets of highly developed industries especially in military related production were established as a result of foreign pressure by more developed neighbours in the West. 'The Russian State, erected on the basis of Russian economic conditions, was being pushed forward by the friendly, and even more by the hostile, pressure of the neighbouring State organizations, which had grown up on a higher economic basis' (Trotsky, 1906/2007: 27). Hence, capitalist expansion is also 
'combined' as a result of 'the sociological outcome of international capitalist pressures on the internal development of non-capitalist societies' (Rosenberg, 2006: 319). In short, in response to the crisis tendency of the capitalist social relations of production, there is an inherent dynamic of outward expansion along uneven and combined lines. There is some discussion to what extent Trotsky envisaged that countries could catch up and overtake already developed countries due to the 'privilege' of their historical backwardness, allowing them to skip stages of development, other countries before them had to go through (Trotsky, 1932/2008: 4). While Trotsky considered this to be possible indeed, it is also clear that this has been rather an exception based on specific historical circumstances (Bieler, 2013: 175-7). While development clearly results from uneven and combined development processes, the gap between advanced industrialised countries and developing countries tends to increase. As Samir Amin has noted,

historical capitalism, as it has really existed, has always been imperialist in the very precise sense that the mechanisms inherent to its worldwide spread, far from progressively 'homogenizing' economic conditions on a planetary scale, have, on the contrary, reproduced and deepened the contrast, counterposing the dominant (imperialist) centers to the dominated peripheries' (Amin, 2010: 84). ${ }^{2}$

Importantly, 'this unevenness is not seen as a result of market imperfections, but is in fact a product of the way competitive markets work in the real world' (Kiely, 2007: 18).

The transnationalisation of production, especially since the early 1970s, has ensured that a lot of manufacturing production has been transferred to countries in the Global South. Already in the mid-1970s, Amin observed how through Foreign Direct Investment (FDI) the way the periphery was integrated into the global economy was being restructured. Through the export of finance, capitalist social relations of production were established in peripheral spaces enjoying the advantage of low-wage costs, while high value-added production based on latest technology, often controlled by Transnational Corporations (TNCs), was retained in the core. Unsurprisingly, this did not result in developmental catch-up but in further entrenching uneven and combined development (Amin, 1976: 185-90). Data provided by Kiely illustrates this conclusion well:

In $1970,18.5$ per cent of the total exports from the developing world were manufactured goods; with the phenomenal rise of China since the early 1990s, this figure had increased to over 80 per cent by the end of the 1990s. However, at the same time, since the liberalization of the 1980s, developed countries' share of manufacturing exports fell (from 82.3 per cent in 1980 to 70.9 per cent by 1997), but their share of manufacturing value added actually increased over the same period, from 64.5 per cent to 73.3 per cent (Kiely, 2012: 239-40).

Hence, the transnationalisation of production has entrenched further unevenness in the global economy, because 'early innovators have "locked in" advantages over later developers and so they tend to accrue a disproportionate amount of the benefits' (Kiely, 2012: 241). As a result of these processes of uneven and combined development, however, it is clear that different national labour movements are in very different positions within the global economy. From the International Workingmen's Association (1864-1876) to today's International Trade Union Confederation and the various sectoral Global Union Federations, there have always been attempts at establishing 
unifying organisations of workers at the international level. And yet, common positions were often difficult as a result of these different positions of national labour movements in the global political economy.

As discussed above, the focus on competitiveness and the tendency towards crisis are structuring conditions of the capitalist social relations of production. Equally, it can be argued that the pressure towards outward expansion is to some extent a structuring condition resulting from the need to overcome crisis and be it on a temporary basis. Nevertheless, it is at this point that one has to be careful not to slide into a purely structuralist argument. First, restructuring within industrialised countries and the intensified exploitation of the existing workforce are always contested and never conflict free. And it is in this contestation, that agency of resistance plays a crucial role. As Cleaver argues, capital's focus on increasing productivity is not only the result of competition with other employers, it is also a response to workers' struggles, establishing a new way of controlling labour (Cleaver, 2000: 89). In turn, Beverly Silver (2003) demonstrated that whenever capital re-located production into new areas to avoid labour unrest in existing facilities, soon new moments of resistance erupted in these new locations. Clearly, in relation to capitalism's outward expansion, the way and the extent to which non-capitalist space is incorporated into capitalist social relations of production will also depend on the level of resistance against this expansion. In other words, while the pressure for outward expansion results from capitalism's crisis tendency, the way this unfolds and the extent to which space is incorporated into capitalism is very much the result of class struggle. 'The production of economic landscapes is the result of political conflict, between labour and capital and between different segments of labour and of capital who might have quite different visions for how the landscape should be structured ...' (Herod, 2006: 158). The next section will look at the agency of labour within the structuring conditions of global capitalism. ${ }^{3}$

\section{The Agency of Labour Within the Global Economy}

If the way outward expansion of capitalism unfolds is the outcome of class struggle, then it is clear that for workers it matters whether the geography of capitalism is shaped in one way rather than another. Nevertheless, in response to capitalist expansion worker solidarity, based on mutual self-interest as well as shared identity resulting from a common position in the production process and the experience of collective struggles (Lindberg, 2014: 135-7), is anything but automatic. Expanded 'free trade' agreements including not only trade in goods, but also trade in services, public procurement, investment measures, intellectual property rights and investor to state dispute settlement mechanisms are currently the most important dynamic driving capitalist expansion (Bieler et al., 2014). The negotiations of the broad Trans-Pacific Partnership Agreement and the Transatlantic Trade and Investment Partnership are testimony to this. In response to this expanded 'free trade' agenda, labour movements from around the world find it difficult to establish a common position. For example, tensions between European trade unions and unions from the Global South over expanded 'free trade' developed into an open confrontation during the talks over the revival of the WTO Doha round in 2008. The European Metalworkers' Federation (EMF) co-operated with the European Automobile Manufacturers' Association (ACEA) in the publication of two joint press releases, demanding reciprocal market access in the Global South (ACEA-EMF, 2008a and 2008b). These joint statements led to an angry response by the Congress of South African Trade Unions (COSATU). The EMF was accused of undermining workers' solidarity, since their co-operation 
with European employers in demanding equal market access would imply job losses in the Global South and undermine the internal unity of the International Trade Union Confederation (COSATU, 2008). Harvey highlights the potential geographical dimensions of class formation. 'In so far as class struggle yields a terrain of compromise between capital and labour within a region, organized labour may rally in support of such alliances in order to protect jobs and privileges already won' (Harvey, 2006: 441), and be it at the expense of workers elsewhere.

How can we explain these instances of co-operation between trade unions and employers at the national and regional level, even though the resulting policies are negative for workers elsewhere? At first sight, the clearest explanation of co-operation between trade unions and employers in the Global North over 'free trade' is of a structuralist nature. As outlined above, due to uneven and combined development underlying the outward expansion of capitalism various national labour movements are in rather different locations within the global social relations of production. Unsurprisingly, it could be argued that, due to structurally different positions, strategies and opinions of these labour movements vary and transnational solidarity cannot occur. If left on its own, however, this understanding collapses into a position of economic determinism, which explains trade unions' strategies simply as a straightforward result of their location in the production process. In reality, the relationship between the structural location and agency of labour is rather more complex. Of course, there is a tendential link between the objective class position of social forces and the particular strategies they adopt. Nevertheless, 'what the economic cannot do is (a) to provide the contents of the particular thoughts of particular social classes or groups at any specific time; or (b) to fix or guarantee for all time which ideas will be made use of by which classes' (Hall, 1996: 44). In other words, within each given set of structuring conditions, agents are not completely free in their actions, but they nonetheless still have a range of strategies at their disposal, from which they can choose how to go forward. Hence, a closer look at the potential rationale underlying agency is required to understand the lack of solidarity. In the next sub-section, two arguments will be discussed in this respect, the idea of a 'labour aristocracy' and the concept of 'false consciousness'.

\section{CLASS BETRAYAL?}

\section{THE CONCEPTS OF 'LABOUR ARISTOCRACY' AND 'FALSE CONSCIOUSNESS'}

It is Lenin, who is frequently associated with the notion of labour aristocracy. When he explained the reasons for the split within the European working classes into revolutionary communists and reformist social democrats, he argued that opportunists, a small section of the working class, had been bribed by capital to maintain capitalist social relations. They had established labour parties with a reformist focus, which did not question capitalism as such. 'Economically, the desertion of a stratum of the labour aristocracy to the bourgeoisie has matured and become an accomplished fact; and this economic fact, this shift in class relations, will find political form, in one shape or another, without any particular "difficulty" (Lenin, 1916: 10). The money to bribe the labour aristocracy came from super profits of the colonial empires. In the words of Bukharin, a close associate of Lenin, 'the colonial policy yields a colossal income to the great powers, i.e., to their ruling classes, to the "state capitalist trust". This is why the bourgeoisie pursues a colonial policy. This being the case, there is a possibility for raising the workers' wages at the expense of the exploited colonial savages and conquered peoples' (Bukharin, 1915/1929: 164). As a result, 'a privileged upper stratum of the proletariat in the imperialist countries lives partly at the expense of hundreds of 
millions in the uncivilised nations' (Lenin, 1916: 2). Clearly, this argument can be related to the EMF's support for the European employers' demand for reciprocal access in free trade agreements. Trade unions and their members operate like this purely out of self-interest. They have become used to their benefits as part of a labour aristocracy and are determined to maintain these benefits at all costs and be it at the expense of labour in the Global South. At times, moreover, the charge of labour aristocracy is also raised against trade unions, organising workers in secure jobs, due to a perceived lack of solidarity with informal labour and other marginalised groups within society.

And yet, such an evaluation would be a gross misrepresentation of workers' situation in the Global North. Unemployment in many European countries is at a record high. 'The EU-28 unemployment rate was $10.8 \%$ in January 2014' (Eurostat, 2014). Moreover, atypical work contracts and flexibilised labour have increasingly become the norm. While work pressure is constantly increased, employment itself has become ever more insecure. The current crisis is used across the EU to undermine European welfare states. Trade unions supporting free trade agreements are not securing privileges of luxury for their members. Rather, they are involved in protecting their members' very basis of existence. Trade union work in the North against the background of the global financial crisis and constant pressures of restructuring is a defensive struggle to retain minimum conditions for workers, not a struggle to secure imaginary riches.

Moreover, divisions within the labour movement are normal and have always existed. They are not the result of bribes, nor necessarily linked to imperialism (Moorhouse, 1978: 68-9). There are no specific mechanisms, which direct the benefits of imperialism to sections of the working class. In any case, the gains made by workers, Moorhouse argues, were made at the expense of employers, not of exploited people elsewhere (Moorhouse, 1978: 76). Eric Hobsbawm acknowledges the existence of a labour aristocracy in $19^{\text {th }}$ century Britain, a nucleus of skilled workers on higher wages (Hobsbawm, 1984: 220, 234). Nevertheless, this does not imply that there was a less privileged section of the working class, which was more revolutionary, while the labour aristocracy demonstrated moderation and reformism. On the contrary, 'the bulk of organized working class activism in the later Victorian and Edwardian periods, leaving aside special cases like mining, came from among this stratum. If anything, the labour aristocracy was therefore the nursery of the left' (Hobsbawm, 1984: 243-4). Along this line, Callinicos further points out that it had been the wellorganized, relatively well-paid metalworkers, who were behind revolutionary struggles after the First World War and joined Communist parties (Callinicos, 2009: 50), i.e. precisely those sections of the working class we would expect to be part of the labour aristocracy and reformist social democratic parties. In short, it would be wrong to accuse trade unions, who co-operate with employers in certain circumstances, of class collaboration. Rather, such issues are a matter of strategy for trade unions.

Nevertheless, if we accept that strategies of co-operation with capital are consciously chosen as the best way forward, would we then not have to conclude that these trade unions operate under conditions of 'false consciousness', not realising their true interests as the result of an incorrect analysis of the situation? Stuart Hall has engaged with the role of ideology from a historical materialist perspective and looked at the issue of 'false consciousness' more closely. He convincingly makes clear that it would be wrong to argue that 'false consciousness' results from an incorrect analysis of economic reality. The problem is not that the analysis is incorrect, the problem is that the analysis is only partial. 'In a world where markets exist and market exchange dominates economic life, it would be distinctly odd if there were no category allowing us to think, speak and act in relation to it. In that sense, all economic categories - bourgeois or Marxist - express existing social 
relations' (Hall, 1996: 36). Because bourgeois economic understanding is so widespread and has become common sense, including within many trade unions, their assessment of the situation is based on this market understanding. And on the basis of this partial understanding it makes perfect sense to co-operate with employers in support of further 'free trade', as 'free trade' is understood to be beneficial for everyone involved. 'The falseness therefore arises, not from the fact that the market is an illusion, a trick, a sleight-of-hand, but only in the sense that it is an inadequate explanation of a process' (Hall, 1996: 37). Parts of reality are invisible, given the concepts and categories used. What is overlooked in many analyses are the implications of the 'hidden abode of production' including private property, wage labour and the expropriation of surplus value and all the relations of inequality and exploitation which come with it.

Empirically, it is important to note that while it is not automatic that different national labour movements co-operate with each other, it is equally not automatic that they co-operate with their own employers at the detriment of workers elsewhere. During the American civil war, for example, cotton unions in the UK supported the boycott of confederate cotton because of their opposition to slavery. And this despite the unemployment amongst workers in the cotton industry resulting from this position (McPherson, 1990: 549-51). ${ }^{4}$ Transnational solidarity is possible, even if it goes against the direct economic interests of a group of workers. Hence, whether transnational solidarity occurs or not is clearly an open-ended issue and may differ from case to case.

When analysing class struggle and the possibility of transnational labour solidarity, the distinction between class-in-itself and class-for-itself is relevant. A class-in-itself can be identified due to the way production is organised, but it may not yet have developed a class consciousness in struggle and, thus, become a class-for-itself. Robinson, for example, argues that transnational labour so far has only developed into a class-in-itself resulting from the organisation of production at the transnational level. 'But this emerging global proletariat is not yet a class-for-itself; that is, it has not necessarily developed a consciousness of itself as a class, or organized itself as such ...' (Robinson, 2004: 43). The transition from a class-in-itself to a class-for-itself is made in class struggle. People, 'experience exploitation (or the need to maintain power over those whom they exploit), they identify points of antagonistic interest, they commence to struggle around these issues and in the process of struggling they discover themselves as classes, they come to know this discovery as classconsciousness' (Thompson, 1978: 149). Hence, although classes-in-themselves can be identified through a focus on the social relations of production, the analytical emphasis then has to turn towards the analysis of class struggle and the potential of forming class consciousness. In short, class struggle is the moment when agency meets structure, when labour meets the structuring conditions of the capitalist social relations of production. Class struggle is the process in which labour identities are formed and transformed. It is the moment when structuring conditions are being confirmed or changed. Hence, it is through the prism of class struggle that we can best analyse trade unions' responses to global restructuring. Whether different labour movements engage in relations of transnational solidarity is not pre-determined by the structuring conditions of the capitalist social relations of production, but ultimately depends on the outcome of class struggle.

\section{ANALYSING CLASS STRUGGLE AND DIVISIONS ALONG ETHNICITY AND GENDER}

Marxist class analysis is frequently criticised for overlooking the struggles over gender, ethnicity, nationalism, the environment, etc. Nevertheless, this focus on class struggle makes it 
possible to go beyond an exclusive focus on the struggle between employers and workers at the workplace or on negotiations or conflicts between employers' associations and trade unions at the national level. As such, capitalism is indifferent to social identities as, for example, ethnicity or gender. Capitalism exploits people regardless of their particular identities. As Ellen Meiksins Wood makes clear, 'if capitalism derives advantages from racism or sexism, it is not because any structural tendency in capitalism toward racial inequality or gender oppression, but on the contrary because they disguise the structural realities of the capitalist system and because they divide the working class' (Wood, 2002: 279). Hence, capital may use these social identities around ethnicity, nationalism and gender for discourses to fragment and divide the working class (Harvey 2006: 383). Trade unions too have on occasion employed a discourse of gender or immigration to protect their white male membership on secure permanent contracts (Ledwith, 2006: 98-9). At the same time, ethnic identity may be an important factor in mobilising collective class agency, as Davide Però illustrates in his analysis of the Latin American Workers Association (LAWAS) and its organising of Latin American workers in London. LAWAS embedded its activists 'in a solidarity circuit where class and ethnicity are interwoven, making them feel stronger and cared about' (Però 2012: 9). Ethnicity, gender and other identities are, therefore, often closely involved in moments of class struggle. Indeed, 'it is difficult to conceive of a society that perpetuates class exploitation without using existing racial and gender differences (and etching new ones) as channels for that exploitation' (Smith 2000: 1026). At the same time, resistance against these forms of exploitation along gender or ethnic lines must not overlook that the fundamental dynamics of exploitation are rooted in the way the capitalist social relations of production are organised. 'The strategic implications are that struggles conceived in purely extra-economic terms - as purely against racism or gender oppression for example - are not in themselves fatally dangerous to capitalism, that they could succeed without dismantling the capitalist system but that, at the same time, they are probably unlikely to succeed if they remain detached from an anticapitalist struggle' (Wood, 2002: 281). In other words, these forms of exploitation must not be confronted in isolation of the fundamental economic exploitation within the social relations of production. 'Feminism that speaks of women's oppression and its injustice but fails to address capitalism will be of little help in ending women's oppression' (Holmstrom, 2002: 2).

Racism, in turn, acquired a unique connotation as a result of capitalism, Wood argues. 'It was precisely the structural pressure against extra-economic difference which made it necessary to justify slavery by excluding slaves from the human race, making them non-persons standing outside the normal universe of freedom and equality' (Wood, 2002: 280). Racism was used to justify colonial plunder and is still employed at times in relation to exploitation of migrant workers, for example, or when enforcing the extraction of raw materials in the Global South. Again, however, racism in itself, similarly to gender, is not a structuring condition of capitalism and ending racism would not end exploitation. The South African experience demonstrates this clearly. During the period of Apartheid, racism and capitalist exploitation were overlapping and reinforcing each other. Nevertheless, as Bond, Desai and Ngwane acknowledge, defeating Apartheid did not end capitalist exploitation. 'We found that Apartheid was conjectural, but uneven and combined development is systematic' (Bond, Desai and Ngwane, 2013: 53). Consequently, in order to transform the political economy fundamentally, the social relations of production need to be transformed and it is here that class agency and strike action is crucial. The potential collective refusal to work directly challenges the core of capitalist exploitation (Smith, 2000: 1027). Hence, rather than getting side-tracked by understanding gender and ethnic struggles as separate from class struggles and without an economic 
dimension, the focus needs to be more closely on the way production, understood in a broad sense, has become re-organised within globalisation.

In the following, I will introduce four ways in which class struggle allows us to think beyond struggles at the workplace: Robert Cox's focus on non-established, informal labour, Harry Cleaver's emphasis on the 'social factory', Kees van der Pijl's analysis of the extension of exploitation into the sphere of social reproduction, and Chandra Talpade Mohanty's grounding of analysis in the experience of the most exploited female workers in the Global South. First, Cox already argued in 1981 that workers in globalisation have become fragmented along two lines. In addition to the division between national labour working in production sectors organised within a country and transnational labour working in transnational production sectors, he identified the division between established labour, workers on permanent contracts in the core of the economy, and non-established labour. The latter 'have insecure employment, have no prospect of career advancement, are relatively less skilled, and confront great obstacles in developing effective trade unions' (Cox, 1981: 148). As part of the transnationalisation of production, we have not only experienced a centralisation of command in the global economy, but also a fragmentation with many aspects of the transnational production process being outsourced and sub-contracted to other companies. Together with a huge influx into urban areas particularly in the Global South, this has led to an increasing casualisation and informalisation of the economy, in which permanent, full-time employment contracts have to a large extent become a feature of the past. In a way, 'it is no longer accurate today', Dan Gallin argued already in 2001, 'to describe the informal sector as "atypical"' (Gallin, 2001: 228). This has always been the case in developing countries, but, informalisation more and more also affects developed countries in the North (Standing, 2011), where employers are on the offensive and demand a flexibilisation of the labour market with the argument that this would be necessary in order to retain competitiveness. In a way, the periphery appears in the core, the South in the North and, of course, vice versa. Trade unions find it extremely difficult, if not impossible, to organise the informal economy in the first place. Hence the need to think beyond traditional trade union organising of workplaces.

Second, when reflecting on the increasing number of struggles of the late 1960s and 1970s, Harry Cleaver asserts that 'the reproduction of the working class involves not only work in the factory but also work in the home and in the community of homes ...; the working class had to be redefined to include nonfactory analysis' (Cleaver, 2000: 70). Analysing what he called the 'social factory' allowed Cleaver to take into account all the other forms of unwaged activities including child rearing, education, which are necessary for the reproduction of capital, but take place outside the workplace. Drawing on the work of the so-called Italian New Left around Mario Tronti and Antonio Negri, he concluded that 'the identification of the leading role of the unwaged in the struggles of the 1960s in Italy, and the extension of the concept to the peasantry, provided a theoretical framework within which the struggles of American and European students and housewives, the unemployed, ethnic and racial minorities, and Third World peasants could all be grasped as moments of an international cycle of working-class struggle' (Cleaver, 2000: 73).

Another attempt to include struggles outside the workplace into class analysis is made by Kees van der Pijl. He argues that neo-liberal capitalism is characterised by the fact that capitalist discipline has now also been further extended within the entire process of social reproduction, involving the exploitation of the social and natural substratum. In response to the commodification of social services and the intensified destruction of the biosphere as well as the disruption of 
traditional life, a whole range of new, progressive but also nationalist right-wing social movements have emerged to defend the environment and sphere of social reproduction (van der Pijl, 1998: 468; see also Bakker and Gill, 2003). This has to be analysed as class struggle as much as exploitation and resistance to it in the workplace. In other words, the struggle of social movements against neoliberal globalisation, for example, can also be conceptualised as class struggle. Of course, cooperation between labour and other social movements is not automatic and free of tensions, but then class struggle too is a contradictory and often conflictual, open-ended process.

Finally, Mohanty from a 'revised race-and-gender-conscious historical materialism' argues that analysis of capitalist exploitation needs to be grounded in the experience of the most exploited workers in the global economy, i.e. female workers, often working from home, in developing countries. 'Any analysis of the effects of globalization needs to centralize the experiences and struggles of these particular communities of women and girls' (Mohanty, 2003: 235). It is from this perspective that capitalist exploitation of workers can be understood in its gendered and racial dimension and the way capitalism uses related discourses to fragment the working class. 'Management exploits and reinforces these ideologies by encouraging women to view femininity as contradictory to factory work, by defining their jobs as secondary and temporary, and by asking women to choose between defining themselves as women or as workers' (Mohanty, 2002: 167). Moreover, 'the explanation also lies in the specific definition of Third World, immigrant women as docile, tolerant, and satisfied with substandard wages' (Mohanty, 2002: 169). Equally, it is especially women, who are most affected by current cuts to public sector jobs and services, partly because the workforce in the public sector is predominantly female, partly because women are more likely to have caring responsibilities or be lone parents (see also Abramovitz, 2002). Hence, when analysing exploitation and resistance in times of austerity, analysis can also be grounded in the experience of women in industrialised countries.

Successful agency against restructuring requires new ways of organising and alliance formation. In the following, I will provide one example each for the four positions just discussed. First, new ways of how to organise informal workers need to be found. Novel types of organisations may be required. StreetNet International is a good example of a non-union organisation mobilising new types of workers in the informal economy. ${ }^{5}$ Organisations, which directly organise street vendors, market vendors and/or hawkers, i.e. workers without a direct employer counterpart, can affiliate to StreetNet International. The goal is to exchange information on how to best organize people in the peripheries of the labour market so that they can represent their interests in the most effective way through local, national and international campaigns. Co-ordinating members especially from Africa, Latin America and Asia makes StreetNet International a truly transnational organisation. ${ }^{6}$

Second, in order to organise resistance across the whole 'social factory' of capitalism, a new definition of 'worker', beyond the direct employee/employer relationship is necessary. 'As this relationship is being replaced by a variety of more diffuse and indirect but nonetheless dependent relationships in the process of production, trade union organising can no longer focus primarily on the employment relationship' (Gallin, 2001: 233). Trade unions as member organisations, therefore, need to reach beyond the workplace. The Argentine Workers' Central Union (CTA), for example, organises, of course, workers. Nevertheless social movements such as environmental groups and individuals, even if they are not workers in a traditional understanding, can also affiliate. ${ }^{7}$ Community Unionism is another way of reaching beyond the workplace. The term 'Community 
Unionism' is used conceptually and practically in a number of different ways. In general, however, 'community unions identify with the broader concerns of their ethnic, racial and geographical communities. The organisations view housing or civil rights or immigration issues as connected to their core mission around worker organising and issues of class and race, class and place, class and gender and class and ethnicity are joined in this model' (Steward et al., 2009: 8). Community unions reach back historically to a tradition, when it was normal that trade unions were involved with issues of working class communities beyond the workplace (Greenwood and McBride, 2009: 201-1). Tattersall distinguishes between (1) coalitions between unions and community organisations, (2) organising workers on the basis of identity, and (3) place-based trade union organising as sub-strands of Community Unionism (Tattersall, 2009: 163). Her case study of a coalition between a teachers' union and a parents and citizens' initiative in Sydney/Australia in the early 2000s illustrates well, how coalition unionism can be very successful at influencing policy-making, when it succeeds in rallying around issues of common concerns. The fact that teachers and parents had successfully campaigned for smaller class sizes made it later easier for teachers to get support from parents for their demand of a salary increase. The moment trade unions connect with issues of relevance beyond their own direct workplace, there is a good chance of being more successful.

Third, referring to van der Pijl's notion of the extension of exploitation into the sphere of social reproduction, the current European Citizens' Initiative (ECI) on Water as a Human Right, a broad alliance of user groups as well as trade unions including the European Federation of Public Service Unions (EPSU), represents a good example. The initiative collected more than 1.85 million signatures between May 2012 and September 2013. The demands of the ECI are threefold: '(1) For the EU to recognise the UN right to water and sanitation into EU law; (2) not to liberalise water services in the EU; and (3) to contribute to achieving access to water and sanitation for all across the world'. ${ }^{8}$ On the one hand, there is the interest of trade unions to keep water provision in public hands, as working conditions are generally better in the public than the private sector. On the other, user groups are supportive of universal access to affordable clean water. It is again this inclusion of issues beyond the workplace, the right to access to clean water, which has allowed these trade unions to link up with other social movements and, thereby, broaden the social basis for resistance and form bonds of solidarity.

Finally, when thinking in terms of resistance by the most exploited women in the global economy, SEWA (Self-Employed Women's Association) (SEWA; http://www.sewa.org/; 14/06/2012) in India, registered as a trade union, but organising predominantly female homeworkers, is one of the most successful examples of organising (Mohanty, 2002: 175). Through initiatives such as its green livelihoods strategy, SEWA has protected the livelihood of many of its 1.3 million female members (Sahoo, 2012). SEWA also provides an excellent example of how these novel forms of organisation can be integrated in global labour institutions. In 2006, it was accepted as affiliate by the International Trade Union Confederation. Not all is well yet. As Gallin points out, this 'was largely a symbolic achievement. The new International had neither a "department" nor a "desk" for informal workers, nor was the informal workers' agenda any part of the priorities of the new organization' (Gallin, 2012: 11). Nevertheless, it points into encouraging directions of organising transnational solidarity in the current structuring conditions of global capitalism. 


\section{Conclusion}

Stuart Hall states that 'what is "scientific' about the Marxist theory of politics is that it seeks to understand the limits to political action given by the terrain on which it operates' (Hall, 1996: 45). Hence, this article initially focused on identifying the structuring conditions of the capitalist social relations of production including the inherent drive towards the constant increase in surplus accumulation, the tendency towards periodic crises as well as processes of uneven and combined development resulting from attempts to overcome crises. Equally, however, it is the task to understand possibilities for successful action towards a transformation of the capitalist social relations of production. In particular, it is in moments of crisis that agency of resistance becomes relevant and influences directly the shape and extent to which strategies of restructuring are established by capital.

The second part of the article looked then in more detail at the agency of resistance and grappled with the problem that labour at times co-operates with capital at the national or regional level, even though this is to the detriment of workers elsewhere. The suggestion that Northern labour's strategies were directly determined by their privileged position within the global economy was rejected. Material circumstances will frame strategic considerations, but there are always several possible strategies available for labour at any one moment in time. Equally, the notion that this may be the result of Northern labour constituting a kind of labour aristocracy or operating on the basis of 'false consciousness' was refuted. Which strategy is ultimately adopted depends on class struggle. Importantly, work and worker need to be defined broadly and struggle needs to go beyond the workplace and the institutional interaction between trade unions and employers' associations. Four ways of conceptualising the possibility for wider struggles were introduced with examples: Cox's focus on non-established, informal labour, Cleaver's emphasis on the 'social factory', van der Pijl's analysis of the extension of exploitation into the sphere of social reproduction, and Mohanty's grounding of analysis in the experience of the most exploited female workers in the Global South.

Of course, in locations where labour is still more closely integrated into the capitalist social relations of production and continues to draw benefits to some extent, and be it ever more decreasing, it may be less likely for a revolutionary moment to occur. When Trotsky analysed the way how Russia had been integrated into the global economy in processes of uneven and combined development at the beginning of the $20^{\text {th }}$ century, his main interest was not simply an assessment of Russian development. Rather, he wanted to understand the structuring conditions of the Russian situation and in what way it may facilitate revolutionary upheaval. The element of combined development is crucial in this respect, since it brings together the most advanced social forms with backward social forms, resulting in rather unstable overall social formations (Davidson, 2010: 13). Countries in the periphery, therefore, are potentially a more fertile ground for revolutionary uprisings than countries in the core with more coherent social formations. 'China and other states like India and Brazil where growth has been less dramatic remain both inherently unstable in their internal social relations and expansive in their external search for markets, raw materials and investment opportunities. It is in this inherent instability that the possibilities for permanent revolution lie' (Davidson, 2010: 17-18).

Thinking about the Eurozone crisis, it should be no surprise therefore that class struggle is fought much more openly on the streets of Athens, i.e. the periphery of Europe, where the exploitation by capital is enforced in a much more open and politically direct, often authoritarian way, than e.g. in the UK, where the cuts are still less violent and less existential for people than in Greece. And indeed, it is in Greece that we can observe wider struggles within the social factory. 
'Especially after 2010, social resistance to austerity included diverse forms of solidarity and initiatives to set up a parallel social economy: from social clinics and pharmacies to social groceries, and from the movement to cut out the intermediaries in agricultural production to various cooperative ventures' (Laskos and Tsakalotos, 2013: 143). This included co-operation between trade unions and wider social class forces. For example, 'the Federation of Hospital Doctors took a number of important initiatives on these lines, climaxing with the establishment of Wednesdays as a day of free access to health care in hospitals for the uninsured' (Laskos and Tsakalotos, 2013: 124). Workers in the core, being in a different location of production due to the overall unevenness of the economy, may initially see their own fortunes in a different light. Nevertheless, as the current crisis in Europe demonstrates, restructuring ultimately affects workers in the periphery and core alike and the situation of workers in the periphery now may simply represent the position of workers in the core in the future. As it was discussed above, class consciousness, the move towards a class-for-itself, emerges in struggle. The challenge is to organise this struggle in a way so that it overcomes the initial divisions of interest between national and transnational, formal and informal labour, between workers in the periphery and the core, as well as fragmentations along ethnic and gender lines.

\section{NOTES}

1. Many thanks to Ian Bruff, Chris Hesketh, Simon Joyce, Ross Longhurst, Adam David Morton, Burak Tansel, Elif Uzgoren, the editors of this special issue as well as two anonymous referees for their feedback on earlier drafts of this article. I am also grateful to colleagues from the Transnational Labour Project at the Centre for Advanced Study in Oslo (see http://transnationallabour.wordpress.com/) for comments as well as the necessary time and space to complete this piece. This article is my conceptual contribution to the collective project.

2. Many thanks to Burak Tansel for drawing my attention to Samir Amin's work here.

3. Struggles of resistance against restructuring are also shaped by the form of state as an arena within and through which these struggles take place. Nevertheless, in my view state structures are secondary to the structuring conditions of global capitalism, which is why they are not discussed here in more detail. For a discussion of how, through drawing on the work of Nicos Poulantzas, it is possible to conceptualise the struggles over the internalisation of the interests of transnational capital within national state forms, see Bieler and Morton (2013/14).

4. Many thanks to Simon Joyce for mentioning this example and reference to me.

5. See, http://www.streetnet.org.za/; 30/03/2014.

6. For an overview of other successful examples of organizing informal workers and the potential involvement of trade unions, see Bonner and Spooner (2011). 
7. Presentation by Bruno Dubrosin, CTA delegate at the tenth Congress of SIGTUR in Perth, Australia on 4 December 2013. Participant observation by the author.

8. See http://www.right2water.eu/news/press-communication-\%E2\%80\%9Cwater-human-right \%E2\%80\%9D-will-submit-certificates-16-million-signatories, accessed 19/12/2013.

\section{REFERENCES}

Abramovitz, M. (2002) 'Still under Attack: Women and Welfare Reform', in Nancy Holmstrom (ed.), The Socialist Feminist Project: A contemporary reader in theory and politics. New York: Monthly Review Press, pp. 216-27.

ACEA-EMF (2008a) 'European metalworkers and auto manufacturers urge EU to better balance trade negotiations' (22 May 2008); [Online] Available at http://www.emf-fem.org/Press/Pressrelease-archive/2008/European-metalworkers-and-auto-manufacturers-urge-EU-to-betterbalance-trade-negotiations [Accessed: 30 March 2014].

ACEA-EMF (2008b) 'European metal workers and auto industry warn that pending Doha deal puts EU manufacturing at risk' (29 July 2008); [Online] Available at http://www.emffem.org/Press/Press-release-archive/2008/European-metalworkers-and-auto-industry-warnthat-pending-Doha-deal-puts-EU-manufacturing-at-risk [Accessed: 30 March 2014].

Amin, S. (1976) Unequal Development: An Essay on the Social Formations of Peripheral Capitalism. trans. B. Pearce. New York: Monthly Review Press.

Amin, S. (2010) The Law of Worldwide Value (new, revised edition). New York: Monthly Review Press.

Bakker, I. and Gill, S. (eds.) (2003) Power, Production and Social Reproduction: Human In/security in the Global Political Economy. Basingstoke: Palgrave.

Bieler, A. (2013) 'The EU, Global Europe and processes of uneven and combined development: the problem of transnational labour solidarity', Review of International Studies. 39(1): 161-83.

Bieler, A., Ciccaglione, B., Hilary, J. and Lindberg, I. (eds.) (2014) 'Free Trade and Transnational Labour, special issue', Globalizations. Vol.11/1.

Bieler, A. and Morton, A.D. (2001) 'The Gordian Knot of Agency-Structure in International Relations: A neo-Gramscian Perspective', European Journal of International Relations. 7(1): 535. 
Bieler, A. and Morton, A.D. (2013/14) 'The Will-O'-The-Wisp of the Transnational State', Journal of Australian Political Economy. 72, 23-51.

Bonner, C. and Spooner, D. (2011) 'Organizing in the Informal Economy: A Challenge for Trade Unions', International Politics and Society. 2: 87-105.

Bond, P., Desai, A. and Ngwane, T. (2013) 'Uneven and Combined Marxism within South Africa's Urban Social Movements', in Colin Barker, Laurence Cox, John Krinsky and Alf Gunvald Nilsen (eds.), Marxism and Social Movements. Leiden, Boston: Brill, pp. 233-55.

Bukharin, N. (1915/1929) Imperialism and World Economy. New York: International Publishers.

Burnham, P. (1995) 'State and Market in International Political Economy: Towards a Marxian Alternative', Studies in Marxism. 2: 135-59.

Callinicos, A. (2009) Imperialism and Global Political Economy. Cambridge: Polity Press.

Cerny, P. (2010) Rethinking World Politics: A Theory of Transnational Neopluralism. Oxford: Oxford University Press.

Cleaver, H. (2000) Reading Capital Politically (second edition). Leeds: Anti/Theses.

COSATU (2008) 'COSATU CEC Statement'. Statement of the COSATU Central Executive Committee held on 1-3 September 2008 (05/09/2008), Johannesburg; [Online] Available at http://www.cosatu.org.za/show.php?ID=1693 [Accessed: 17 January 2014].

Cox, R.W. (1981) 'Social Forces, States and World Orders: Beyond International Relations Theory', Millennium: Journal of International Studies. 10/2: 126-55.

Davidson, N. (2010) 'From Deflected Permanent Revolution to the Law of Uneven and Combined Development', International Socialism. No. 128; [Online] Available at http://www.isj. org.uk/?id=686 [Accessed: 30 March 2014].

Eurostat (2014) 'Recent developments in unemployment at a European and Member State level', [Online] Available at http://epp.eurostat.ec.europa.eu/statistics_explained/index.php/ Unemployment_statistics [Accessed: 30 March 2014].

Gallin, D. (2001) Propositions on Trade Unions and Informal Employment in Times of Globalisation, in P. Waterman \& J. Wills (eds.), Place, Space and the New Labour Internationalisms. Oxford: Blackwell, pp. 227-45.

Gallin, D. (2012) 'Informal economy workers and the international trade union movement: an overview', paper presented at the Critical Labour Studies $8^{\text {th }}$ Symposium, University of Salford/UK; 18 - 19 February 2012. 
Greenwood, I. and McBride, J. (2009) 'Conclusion', in Jo McBride and Ian Greenwood (eds.) Community Unionism: A Comparative Analysis of Concepts and Contexts. Basingstoke: Palgrave, pp. 210-20.

Hall, S. (1996) 'The problem of ideology: Marxism without guarantees', in David Morley and K.-H. Chen (eds.), Stuart Hall: Critical Dialogues in Cultural Studies. London: Routledge, pp. 25-46.

Harvey, D. (1985) 'The Geopolitics of Capitalism', in D. Gregory and J. Urry (eds.), Social Relations and Spatial Structures. London: Macmillan, pp. 128-63.

Harvey, D. (2006) The Limits to Capital (new and fully updated edition). London: Verso.

Heinrich, M. (2012) An Introduction to the Three Volumes of Karl Marx's Capital. New York: Monthly Review Press.

Herod, A. (2006) Trotsky's Omission: Labour's Role in Combined and Uneven Development, in H. Radice \& B. Dunn (eds.), 100 Years of Permanent Revolution: Results and Prospects. London: Pluto Press, pp. 152-65.

Held, D. and McGrew, A. (2002) Globalization/Anti-Globalization. Cambridge: Polity.

Hobsbawm, E. (1984) Workers: Worlds of Labor. New York: Pantheon Books.

Holloway, J. and Picciotto, S. (1977) 'Capital, Crisis and the State', Capital \& Class. 2: 76-101.

Holmstrom, N. (2002) 'Introduction', in Nancy Holmstrom (ed.), The Socialist Feminist Project: A contemporary reader in theory and politics. New York: Monthly Review Press, pp. 1-12.

Kiely, R. (2007) The New Political Economy of Development: Globalization, Imperialism, Hegemony. London: Palgrave.

Kiely, R. (2010) Rethinking Imperialism. London: Palgrave.

Kiely, R. (2012) 'Spatial hierarchy and/or contemporary geopolitics: what can and can't uneven and combined development explain?', Cambridge Review of International Affairs. 25(2): 231-48.

Laskos, C. and Tsakalotos, E. (2013) Crucible of Resistance: Greece, the Eurozone and the World Economic Crisis. London: Pluto Press.

Ledwith, S. (2006) 'The Future as Female? Gender, Diversity and Global Labour Solidarity', in C. Phelan (ed.), The Future of Organised Labour: Global Perspectives. Oxford et al.: Peter Lang, pp. 91-134. 
Lenin, V.I. (1916) Imperialism and the Split in Socialism, [Online] Available at www.marxists. org/archive/lenin/works/1916/oct/x01.htm [Accessed: 6 February 2012].

Lindberg, I. (2014) 'Unions and Trade: What Kind of Solidarity?', Globalisations. Vol.11/1: 131-41.

Luxemburg, R. (1913/2003) The Accumulation of Capital. (translated by. Agnes Schwarzschild). London: Routledge.

Marx, K. (1867/1990) Capital, Volume 1. London: Penguin.

Marx, K. and Engels, F. (1848/1998) Manifesto of the Communist Party, in M. Cowling (ed.), (1998) The Communist Manifesto: New Interpretations. Edinburgh: Edinburgh University Press, pp. 14-37.

McPherson, J.M. (1990) Battle Cry of Freedom: The American Civil War. London: Penguin.

Mohanty, C.T. (2002) 'Women Workers and Capitalist Scripts: Ideologies of domination, common interests, and the politics of solidarity', in N. Holmstrom (ed.), The Socialist Feminist Project: A contemporary reader in theory and politics. New York: Monthly Review Press, pp. 160-80.

Mohanty, C.T. (2003) Feminism Without Borders: Decolonizing theory, practicing solidarity. Durham/London: Duke University Press.

Moorhouse, H.F. (1978) 'The Marxist Theory of the Labour Aristocracy', Social History. 3(1): 6182.

Nilsen, A.G. (2009) "“The authors and the actors of their own drama”: Towards a Marxist theory of social movements', Capital \& Class. 99: 109-39.

Però, D. (2014) 'Class Politics and Migrants: Collective Action among New Migrant Workers in Britain', Sociology. [Online] first on 13/03/2014 at http://soc.sagepub.com/content/early/ 2014/03/13/0038038514523519 [Accessed: 30 March 2014].

van der Pijl, K. (1998) Transnational Classes and International Relations. London: Routledge.

Robinson, W.I. (2004) A Theory of Global Capitalism: Production, Class, and State in a Transnational World. Baltimore/London: John Hopkins University Press.

Rosenberg, J. (2006) 'Why is there no International Historical Sociology?', European Journal of International Relations. 12(3): 307-40.

Sahoo, S. (2012) 'Organizing informal women workers for green livelihoods: the Self Employed Women's Association in Gujarat', in S. Mosoetsa and M. Williams (eds.) Labour in the global South: Challenges and alternatives for workers. Geneva: ILO, pp. 181-99. 
Silver, B.J. (2003) Forces of Labor: Workers' Movements and Globalization since 1870. Cambridge: Cambridge University Press.

Smith, N. (2000) 'What happened to class?', Environment and Planning A. 32: 1011-32.

Standing, G. (2011) The Precariat: The New Dangerous Class. London: Bloomsbury Academic.

Stewart, P. et al. (2009) 'Introduction', in J. McBride and I. Greenwood (eds.), Community Unionism: A Comparative Analysis of Concepts and Contexts. Basingstoke: Palgrave, pp. 13-20.

Tattersall, A. (2009) 'Using their Sword of Justice: The NSW Teachers Federation and its Campaigns for Public Education between 2001 and 2004', in J. McBride and I. Greenwood (eds.), Community Unionism: A Comparative Analysis of Concepts and Contexts. Basingstoke: Palgrave, pp. 161-86.

Thompson, E.P. (1978) 'Eighteenth-Century English Society: Class Struggle Without Class?', Social History. 3(2): 133-65.

Trotsky, L. (1906/2007) 'Results and Prospects', in L. Trotsky, The Permanent Revolution and Results and Prospects. Introduction by Michael Löwy, London: Socialist Resistance, pp. 24-100.

Trotsky, L. (1932/2008) History of the Russian Revolution. Chicago: Haymarket Books.

Waltz, K.N. (2000) 'Globalization and American Power', The National Interest. 59: 46-56.

Wood, E.M. (1995) Democracy Against Capitalism: renewing historical materialism. Cambridge: Cambridge University Press.

Wood, E.M. (2002) 'Capitalism, and Human Emancipation: Race, Gender, and Democracy', in N. Holmstrom (ed.), The Socialist Feminist Project: A contemporary reader in theory and politics. New York: Monthly Review Press, pp. 277-92.

Wright, E.O. (2006) 'Compass Points: Towards a Socialist Alternative', New Left Review. 41: 93124.

\section{BIOGRAPHICAL NOTE}

ANDREAS BIELER is Professor of Political Economy and Fellow of the Centre for the Study of Social and Global Justice in the School of Politics and International Relations at Nottingham University, Nottingham, UK. His personal website is www.andreasbieler.net and he maintains the blog Trade unions and global restructuring at http://andreasbieler.blogspot.co.uk/.

[email: Andreas.Bieler@nottingham.ac.uk] 